\title{
Comparison of marital satisfaction by couples types in arranged (ta'aruf) married couples
}

\author{
Shahnaz Safitri ${ }^{1}$, Yudiana Ratna Sari ${ }^{2}$ \\ ${ }^{1,2}$ Faculty of Psychology, Universitas Indonesia, Indonesia \\ ${ }^{1}$ shahnazsafitri@ui.ac.id., 2yudianaratnasari@gmail.com
}

\section{ARTICLE INFO}

\section{Article history}

Received 26 December 2018

Revised 17 September 2019

Accepted 26 September 2019

\section{Keywords}

couple types

marital satisfaction

ta'aruf

\begin{abstract}
ABSTR ACT
One form of marital arrangements in Indonesian Muslim society is to get married through arranged marriages, popularly called as ta'aruf. Ta'aruf is related to the individual's religiosity, which may be associated with high marital satisfaction. This study aimed to explore the comparison of marital satisfaction by couple types in the context of marriage through ta'aruf. This research involved 62 persons as couples ( $M$ of age $=25.35$ years old) in Jakarta as participants. The Revised Dyadic Adjustment Scale (RDAS) and Relational Dimensions Instrument (RDI) were used to collect the data. The couple types were derived from K-Means cluster analysis on the RDI score which was further analyzed with one-way ANOVA to test for difference in marital satisfaction. The results show there is a significant difference in marital satisfaction among the couple types in the couples as general, and also particularly in men as husbands. However, marital satisfaction does not differ to the couple type among women as wives. Therefore, gender seems to influence this relationship since husbands and wives differ in their degree of marital satisfaction within the same couple types. The compatibility on the vision and marital scheme between the spouses may enforce to a high marital satisfaction.
\end{abstract}

\section{Introduction}

Human development can be categorized into several phases of life, starting from infancy to late adulthood. During young adulthood developmental stage, the individual has to fulfill several developmental tasks to adapt optimally into a well-adjusted life. One of these tasks is to build intimacy which can be done through forming and fostering marital relations (Papalia, Olds, and Feldman, 2009). Williams, Sawyer, and Wahlstrom (2006) stated that marital relationship is a distinct relationship that brings the union between man and woman into a socially and legally accepted status by the community. The importance of the marital relationship is also established in Indonesia by Law Number 1/1974 that describes marriage as "...an inner bond between man and woman as husband and wife to form a happy and eternal family in the name of God".

Marriage is commonly viewed as the highest form of a committed relationship (Miller, 2012), which offers intimacy, friendship, affection, companionship, fulfillment of sexual needs, opportunities to enhance emotional skills, and fulfillment of spiritual needs. It also functions as one's source of identity and self-esteem (Papalia et al., 2009). Also, marriage functions as a unit of consumption and cooperation in meeting economic needs (Strong, DeVault, and Cohen, 2011). Regarding its functions, both spouses usually expect to be successful in establishing marriage by being remained in the bond throughout their lives (Baron, Byrne, and Branscombe, 2009). 
The extent to which marriage fulfills a person's expectations is then related to this person's satisfaction with the marriage. DeGenova (2008) defined marital satisfaction as a "...subjective evaluation of a marital relationship as a good, happy, or satisfying". Marital satisfaction is also defined as a comprehensive evaluation of one's marriage and satisfaction then indicates marital happiness (Arif and Fatima, 2015). The more expectations are fulfilled in the marriage, the more satisfied the individual is. Furthermore, marital satisfaction is also known to be the central aspect of the success of marriage (Fitzpatrick, 1988; DeGenova, 2008).

Many variables are influencing marital satisfaction, including the background and characteristics of the partner, therefore the different approach that is taken in selecting a partner is significantly affecting the success of a marriage (Miller, 2012). Meanwhile, the procedures, rules, and criteria for selecting a partner are varied across cultures. In an individualistic culture, the individual selects his/her partner. Wherein collectivist culture, the individual's family often interferes with the selection process (Arif and Fatima, 2015). Despite this variability, a substantial time for both individuals to get to know each other before marriage leads to high marital satisfaction (Miller, 2012).

One practice of courtship among Muslims in Indonesia is ta'aruf; an Arabic terminology means "getting to know each other to build mutual understanding" (Hana, 2012). In the context of marriage, ta'aruf means knowing the opposite sex to find a life companion (Hana, 2012; Kinanthi and Sakinah, 2018). Ta'aruf is a courtship according to the Islamic values, with no physical contact and feeling of love or belonging allowed between involved parties before marriage. Thus, ta'aruf requires a mediator for partners to interact (Pusparini, 2012; Kinanthi and Sakinah, 2018). Moreover, the period of ta'aruf is commonly three months before the wedding. Ta'aruf is said to be the recommended procedure in Islam in looking for potential life partners, where another form of courtship is forbidden (Hana, 2012; Kinanthi and Sakinah, 2018). Therefore, devout Muslims usually do not engage in dating but go through ta'aruf (Kinanthi and Sakinah, 2018).

Examining through the previous framework, an individual's decision to married through ta'aruf is a manifestation in carrying out religious orders in the process of finding a spouse (Kinanthi and Sakinah, 2018). Thus, it might help to foster marital satisfaction (Henderson, Ellison, and Glenn, 2018). Couples who marry through ta'aruf are two individuals who both uphold Islamic values in finding a partner. As both parties are basing their decision to marry on Islamic values, this refers to the similarity of their views as a joint worship activity in entering marriage, a matter that is positively related to marital satisfaction (Wilmoth, Blaney, and Smith, 2015; Henderson, Ellison, and Glenn, 2018). On the other hand, the procedure of ta'aruf with its limitations in courtship tends to lower marital satisfaction (Miller, 2012) since it limits the quality of knowing their partners before marriage (Kinanthi and Sakinah, 2018). Therefore only the superficial information being uncovered about the partner during the ta'aruf (Musrifah, 2017), which lead both individuals to make a hopeful assumption about their partner based on the impression on the curriculum vitae, discussion content, and some personal attributes such as education level, occupation, physical feature, family relationship, age, and ethnic (Supratman and Mardianti, 2016).

Apart from marriage preparation, marital satisfaction is also influenced by the characteristics that couples possess within their marriage (Fitzpatrick, 1988). In the case couple married through ta'aruf, they often try to develop and intensify their relationship using self-disclosure after marriage (Musrifah, 2017). Therefore, exploring their couple's characteristics during their marriage is crucial for these couples. The couples' characteristics are categorized by Fitzpatrick (1988) based on the pattern of 
communication and interaction in several dimensions, namely the ideology of conventional-unconventional, degree of interdependence-autonomy, and degree of conflict engagement-avoidance.

The first dimension, conventional-unconventional ideology, refers to beliefs, standards, and values that individuals have concerning relationships and family (Fitzpatrick, 1988; Fitzpatrick and Best, 1979). The conventional-unconventional dimension is the main basic distinction among couples and directs how the interaction is built between couples, depicted the range of preferring stability and predictability or change and uncertainty. The second dimension, interdependence-autonomy dimension, is the degree of sharing and companionship between couples, which depicted the use of time and place together. The third dimension, conflict engagement-avoidance dimension, refers to how far individuals want to be involved in a conflict with their partners and being assertive in addressing differences and other conflict-triggering factors. Based on these dimensions, it is possible to categorize married couples into four groups: traditional, independent, separated, and mixed (Givertz, Segrin, and Hanzal, 2009; Mustafa, Hasim, Aripin, and Hamid, 2012).

The first couple type is the traditional type who has conventional ideology related to marital relations. They emphasize stability in relationships, traditional customs, and interdependence between partners. The couple also believes in traditional gender roles (Mustafa et al., 2012). Interdependence appears in terms of a high degree of sharing between couples, the same daily routine, and not too much autonomy in the use of space (Givertz et al., 2009). The couple tends to avoid conflict and is not assertive unless there are serious issues (Mustafa et al., 2012). The second couple type is the independent type who adheres to unconventional values regarding the family and marital relationship. They believe that marriage is not an excuse to curb individual freedom. This group also has a high degree of sharing and companionship, but they maintain physical distance to create privacy with a separate daily routine. Couples of this type frequently have difficulty in managing their daily schedules. Independent type is assertive without hesitation in engaging in conflict if there is a problem (Fitzpatrick, 1988). The last type is the separated type who tends to be ambivalent and simultaneously holds opposite ideologies in their marriage. Couples of this type adopt conventional ideology related to marriage and family issues but also support the importance of individual freedom. This group has a low degree of sharing and companionship between partners, where there is a psychological and physical distance to maintain autonomy. Autonomy itself is a characteristic of this type (Givertz et al., 2009). The primary way for couples to show cooperation is having a daily routine and avoiding conflict. These first three couple types, traditional, independent, and separated, are known as a pure couple, where husband and wife are similar in the dimensions measured. If there is a difference between husband and wife, they then categorized as a mixed couple (Fitzpatrick, 1988; Givertz et al., 2009).

Studies of the relationship between couple types and marital satisfaction found that traditional couples have higher marital satisfaction than other types (Fitzpatrick, 1988; Fitzpatrick and Best, 1979; Givertz et al., 2009). However, the majority of studies were conducted on Caucasian subjects in Western societies with individualistic cultures, who are known to expect a romantic relationship before the marriage (Goodwin, 1999). Other studies such as by Fincham and Beach (2006) also mentioned that research on marital satisfaction so far has a narrow-focused in exploring marital satisfaction as experienced only by western societies (Fincham and Beach, 2006).

One study exploring marital satisfaction in a non-western society is conducted by Mustafa et al. (2012). They found that in Malaysian couples, the traditional couple type 
has the highest marital satisfaction. However, in this research, it was found that the ethnic variable moderates the relationship between couple type and marital satisfaction through ideology. Malay couples have the highest marital satisfaction as a traditional type, while Chinese and Indian couples in Malaysia have the highest marital satisfaction as an independent type. The ethnic variable comes into this condition by influencing the ideology with cultures unique to a particular ethnicity. Local Malay culture is in line with the traditional type of marriage, while Chinese and Indians, since they are living in more urban areas, are developing cultures in line with independent type.

Based on the studies above, this research aims to explore further the dynamic of marital satisfaction in different couple types of individuals who got married through the ta'aruf process. Previous research such as Mustafa et al. (2012) highlighted that Islamic values tend to shape couples into a traditional type, which brings the highest marital satisfaction. The Islamic value shapes couples into traditional type particularly through the dimension of conventional ideology, which reinforces couples to adhere to the traditional custom on gender roles and become interdependence to each other as good virtues. However, the couples who married through ta'aruf face particular challenges in their marriage adjustment due to the limitation possess by ta'aruf, which further affects their satisfaction on the marriage (Kinanthi and Sakinah, 2018). Therefore, this research aims to explore the marital satisfaction among couples married using the ta'aruf process and to compare and contrast the marital satisfaction based on the couple types developed from these couples. Besides, we also aim to compare marital satisfaction by couple types developed in men and women respectively.

\section{Method}

\section{Participant}

This research involved 62 participants from 32 couples (50\% male and 50\% female; M-age $=25.35)$ who were married through ta'aruf process with marital duration no longer than eight years. The duration of participants' marriage was controlled since the newlywed is a period of marital adjustment for couples, especially for those who married through ta'aruf (Musrifah, 2017). The researcher also provided a data control to the participant containing questions related to demographics, as well as duration and mediator of the ta'aruf. The control process is done as a proxy to ensure that the participant is indeed previously married through ta'aruf and also to match a participant with their spouse.

The sampling technique used in this research was accidental sampling, where participation was involved based on willingness (Gravetter and Forzano, 2009). This technique was chosen on the ground that researchers did not know the exact number of the population of couples married through ta'aruf in Indonesia. Data was gathered through online and printed questionnaires containing items measuring marital satisfaction and couple types. The online questionnaire was used to ensure the anonymity and truthfulness of response, considering that the topic might be considered sensitive matter thus is prone to result in false-positive responses (Isma and Turnip, 2019). For the online questionnaire, the researchers spread it through social media to be filled by those possessing the characteristics needed. For the printed questionnaire, the researchers delivered it to the member of several mosques, which are known to facilitate the ta'aruf process for their members.

Of the 113 questionnaires obtained, 62 data from 31 couples were eligible for further process. The rest of the questionnaires were filled only by the husband or by the wife, therefore difficult to differentiate which couple type they belonged to. Thus, the participants analyzed were $\mathrm{N}=62$ individuals who were married through ta'aruf (M- 
age $=25.35$ years, with $\mathrm{M}$-age male $=26.06$ years and $\mathrm{M}$-age female $=24.64$ years $).$ The participants' marriage duration are ranging from 1 month to 83 months ( $M=20.75$ months), with the average $t a^{\prime} a r u f$ duration of $\mathrm{M}=3.931$ months, ranging from 1 week to 1 year. The details of the participant's characteristics are displayed in Table 1.

Table 1

Descriptive Statistic of Participant's Demographic

\begin{tabular}{llc}
\hline \multicolumn{1}{c}{ Characteristic } & \multicolumn{1}{c}{ Type } & Percentage (\%) \\
\hline \multirow{3}{*}{ Occupations } & Entrepreneurs & 19.35 \\
& Housewives & 19.35 \\
& Private employee & 16.12 \\
& Lecturer/teacher & 14.51 \\
& Civil servant & 9.67 \\
Student & 8.06 \\
Ethnicity & Others & 12.90 \\
& Javanese & 40.32 \\
Education Level & Sundanese & 19.35 \\
& Minangkabau & 11.29 \\
& Others & 29.04 \\
& Undergraduate & 70.96 \\
Number of Children & Graduate & 12.90 \\
& High school diploma & 9.68 \\
& Vocational study & 6.46 \\
& None & 51.62 \\
& One child & 45.16 \\
& Two children & 3.22 \\
& Religious teachers & 35.49 \\
& Friends & 35.48 \\
& Family members & 20.97 \\
& Others & 8.06 \\
\hline
\end{tabular}

Table 1 shows that the participants of the study are quite diverse even though all of them were married through ta'aruf.

\section{Study Design}

This study is a cross-sectional with a non-experimental design because the variables are examined as given without any intervention by the researcher (Kumar, 2019).

\section{Instrument}

The Revised Dyadic Adjustment Scale (RDAS) by Busby, Christensen, Crane, and Larson (1995) was used to measure marital satisfaction, while the Relational Dimensions Instrument (RDI) by Fitzpatrick (1988; Mustafa et al., 2012) was used to determine the couple type. We adapted the instrument qualitatively by using the technique of backtranslating from English to the Indonesian language, followed by expert judgment on the items. The readability test was conducted on a group of eight individuals with the same characteristics as the participant (married by ta'aruf) with a focus group discussion to recognize the participants' marriage dynamics related to the ta'aruf process. The result of both the back-translation process and the readability test for each research instruments can be seen in Table 2. 
Table 2

Example of Qualitative Item Adaptation

\begin{tabular}{|c|c|c|}
\hline Prior Item & Translation & Back Translation \\
\hline \multicolumn{3}{|l|}{ RDAS Items } \\
\hline $\begin{array}{l}\text { To what extent do you and your } \\
\text { spouse agree regarding the matters } \\
\text { below? }\end{array}$ & $\begin{array}{l}\text { Seberapa jauh tingkat kesepakatan } \\
\text { antara Anda dan pasangan terkait hal } \\
\text { di bawah ini? }\end{array}$ & $\begin{array}{l}\text { To what extent that both of you agree } \\
\text { to each other as a couple about the } \\
\text { matters below? }\end{array}$ \\
\hline 1. Demonstrations of affection & 1. Ekspresi kasih sayang & 1. Demonstrations of affection \\
\hline $\begin{array}{l}\text { Please indicate how often each of } \\
\text { these questions happens in your } \\
\text { marriage. }\end{array}$ & $\begin{array}{l}\text { Silakan tunjukkan seberapa sering } \\
\text { pertanyaan berikut ini terjadi di dalam } \\
\text { pernikahan Anda. }\end{array}$ & $\begin{array}{l}\text { Please indicate how frequently each } \\
\text { of these questions happens in your } \\
\text { marriage. }\end{array}$ \\
\hline $\begin{array}{l}\text { 7. Do you ever regret that you } \\
\text { married (or lived together)? }\end{array}$ & $\begin{array}{l}\text { 7. Apakah anda pernah merasa } \\
\text { menyesal sudah menikah? }\end{array}$ & $\begin{array}{l}\text { 7. Do you ever feel regret being } \\
\text { married? }\end{array}$ \\
\hline \multicolumn{3}{|l|}{ RDI Items } \\
\hline $\begin{array}{l}\text { In our house, we keep a fairly } \\
\text { regular daily time schedule }\end{array}$ & $\begin{array}{l}\text { Kami menjaga rutinitas jadwal harian } \\
\text { di rumah }\end{array}$ & $\begin{array}{l}\text { We keep the routine of daily } \\
\text { schedule in the house }\end{array}$ \\
\hline $\begin{array}{l}\text { My mate complains if I open } \\
\text { his/her personal mail without } \\
\text { permission }\end{array}$ & $\begin{array}{l}\text { Pasangan saya mengeluh jika saya } \\
\text { membuka pesan pribadinya (email, } \\
\text { SMS, dll) tanpa izin }\end{array}$ & $\begin{array}{l}\text { My spouse complains if I open } \\
\text { his/her private message (email, SMS, } \\
\text { etc) without permission }\end{array}$ \\
\hline
\end{tabular}

\section{a. Revised Dyadic Adjustment Scale (RDAS)}

RDAS instrument measures three dimensions of marital satisfaction: consensus, cohesion, and satisfaction. Consensus refers to the agreement about the essential things in marriage. Satisfaction refers to the degree of conflict during the marriage. Cohesion, the last dimension, refers to the climate of positive interaction and joint activity between spouses (Busby, Christensen, Crane, and Larson, 1995). RDAS has 14 items with the available respond type is a Likert scale from 0 to 5 . For the dimension of satisfaction and cohesion, 0 indicates "never" while 5 indicates "always". Especially for the dimension of consensus, 0 indicates "always disagree" while 5 indicates "always agree". The example of item in the RDAS measure used in the study can be seen in Table 3 .

Table 3

Example of Items from Adapted RDAS

\begin{tabular}{|c|c|c|}
\hline Dimensions & Item Number & Example of Items \\
\hline Consensus & $1,2,3,4,5,6$ & $\begin{array}{l}\text { To what extent do you and your spouse agree regarding the matters below? } \\
\text { 1. Religious matters } \\
\text { 2. Demonstrations of affection } \\
\text { 3. Making major decisions } \\
\text { 4. Sex relations } \\
\text { 5. Conventionality } \\
\text { 6. Career decisions }\end{array}$ \\
\hline Satisfaction & $7,8,9,10$ & $\begin{array}{l}\text { Please indicate how often each of these questions happens in your } \\
\text { marriage. } \\
\text { 7. How often do you discuss or have you considered divorce, separation, or } \\
\text { terminating your relationship? } \\
\text { 8. How often do you and your spouse quarrel? } \\
\text { 9. Do you ever regret that you married (or lived together)? } \\
\text { 10. How often do you and your spouse "get on each other's nerves"? }\end{array}$ \\
\hline Cohesion & $11,12,13,14$ & $\begin{array}{l}\text { How often would you say the following events occur between you and } \\
\text { your spouse? } \\
\text { 11. Engage in outside interests together } \\
\text { 12. Have a stimulating exchange of ideas } \\
\text { 13. Work together on a project } \\
\text { 14. Calmly discuss something }\end{array}$ \\
\hline
\end{tabular}


The reliability of the RDAS was tested through the Cronbach alpha $(\alpha)$ coefficient to look at the test homogeneity (Anastasi and Urbina, 1997) which results in $\alpha=.700$. This value means that the RDAS is internally consistent (Kaplan and Saccuzzo, 2005).

\section{b. Relational Dimensions Instrument (RDI)}

The RDI used to determine the couple types. There are four possible couple types found from RDI: traditional type, independent type, separated type, and mixed type. The types are derived from the three dimensions of the couple relationship, namely dimension of conventional-unconventional ideology, the dimension of interdependence- autonomy, and the dimension of conflict engagement-avoidance, which measured by eight factors. The factors contained are (1) ideology of uncertainty and change, (2) ideology of traditionalism, (3) autonomy, (4) undifferentiated space, (5) temporal regularity, (6) sharing, (7) conflict avoidance, and (8) assertiveness. Each factor is represented by three items, thus the RDI instrument consists of 24 items with the available response is a Likert scale from 0 to 6 . The 0 indicates "never" while 6 indicate "always". The example of RDI items can be seen in Table 4 .

Table 4

Example of Items from Adapted RDI

\begin{tabular}{|c|c|c|}
\hline Factors & Item Number & Example of Items \\
\hline Autonomy & $4,10,18$ & $\begin{array}{l}\text { 4. I have my private room in the house (room for study, workspace, etc.) } \\
\text { 10. My spouse has his/her private room in the house (room for study, } \\
\text { workspace, etc.) }\end{array}$ \\
\hline Space & $2,8,13$ & $\begin{array}{l}\text { 18. I need to have a personal space apart from my spouse. } \\
\text { 2. I open my spouse's private mail (email, message, etc.) without asking } \\
\text { his/her permission } \\
\text { 8. My spouse is annoyed if I happen to open his/her personal mail (email, } \\
\text { message, etc) without his/her consent. } \\
\text { 13. I feel disturbed if the guests in my house trying to entertain themselves } \\
\text { without asking for my permission first (for example: brewing their own } \\
\text { coffee). }\end{array}$ \\
\hline
\end{tabular}

The validity test used to adapt the RDI is confirmatory factor analysis (CFA). For CFA, the factor loading cut-off was set at a minimum level of .20, and the t-value was set at 1.96 (Hair, Black, Babin, and Anderson, 2010). The result of the CFA shows that of the eight factors mentioned in theory, there are only five factors that are fitted with the data to be classified as valid. The other three factors have factor loading below .2 with a t-value of less than 1.96. Thus, we eliminated items from these factors, which result in the remaining five factors have factor loadings ranging from .350 to .630 ( $t$ value $>1.96$ ). Therefore, these five factors consist of 15 items that are valid to measure couple types. All the factors that represent the three dimensions in the RDI instrument can be seen in Table 5 .

Ghozali and Fuad (2008) stated that there are also several indicators to determine if the instrument model fits the data gathered. The index includes chi-square and $p$-value, CFI, GFI, and IFI. The results of the factor analysis show that the measuring instrument has a chi-square value of 4.26 ( $p>.05$ ), which means that the theoretical model of the instrument fits the data. Furthermore, for the CFI, GFI, and IFI coefficients, the whole has a coefficient higher than .9, which indicates that the instrument is fit to the theoretical model being measured (Ghozali and Fuad, 2008). Another perspective from Hair et al. (2010) stated that the RMSEA of the model must be below .05 in which the current model perfectly meets this criterion with RMSEA $=.000$. Therefore, this study uses only five factors with each being measured by three items, which amount to a total of 15 items. 
Table 5

Dimensions and Factors of Couple Types from CFA Result

\begin{tabular}{llcc}
\hline \multicolumn{1}{c}{ Dimension } & \multicolumn{1}{c}{ Factors } & T Value & Factor Loading \\
\hline \multirow{2}{*}{ Conventional-Unconventional } & Ideology of Uncertainty and & $2.84^{*}$ & $.39^{* *}$ \\
Ideology & Change & & .21 \\
& Ideology of Traditionalism & 1.73 & $.63^{* *}$ \\
Interdependence- Autonomy & Autonomy & $4.23^{*}$ & $.47^{* *}$ \\
& Undifferentiated Space & $3.37^{*}$ & $.43^{* *}$ \\
& Temporal Regularity & $3.10^{*}$ & .06 \\
Conflict Engagement-Avoidance & Sharing & .66 & $.35^{* *}$ \\
& Conflict Avoidance & $2.49^{*}$ & .17 \\
\hline
\end{tabular}

${ }^{*} \mathrm{~T}$ value $>1.96 ;{ }^{* *}$ Factor loading $>.2$

Concerning the fact that this research uses only five factors from the original RDI instrument, there are other researches that also adapted RDI to fit the targetted population. A pilot study of couple types by Fitzpatrick and Ritchie (1994 as cited in Mustafa et al., 2012) only uses three factors of RDI: sharing, ideology of traditionalism, and conflict avoidance. All these three factors are representing the three couple types dimensions. Another study by Mustafa et al. (2012) in the Malaysia population uses four factors that also still adequately representing each dimension of couple types. Thus, this study with five factors measuring the three dimensions of couple types can be regarded as adequate.

\section{Data Analysis}

A cluster analysis of K-Means Cluster Sampling using SPSS 17.0 is used to determine the type of couple as gathered from the RDI. This technique will divide the participants into a group according to their pattern of response to the factors measured in RDI. As shown in Table 6 , we found that each RDI factor was significantly different for each couple type group found. It appears that these factors play an essential role in the formation of the cluster type, considering the value of $\mathrm{F}$ is significant at $p<.001$ (Mustafa et al., 2012).

Table 6

Description of Factors on RDI based Couple Types

\begin{tabular}{|c|c|c|c|c|c|c|c|}
\hline \multirow{3}{*}{ Factors } & \multicolumn{6}{|c|}{ Couple Types } & \multirow{3}{*}{$\mathrm{F}$} \\
\hline & \multicolumn{2}{|c|}{ Separated } & \multicolumn{2}{|c|}{ Independent } & \multicolumn{2}{|c|}{ Traditional } & \\
\hline & $\mathrm{M}$ & $\mathrm{Z}$ & $\mathrm{M}$ & $\mathrm{Z}$ & $\mathrm{M}$ & $\mathrm{Z}$ & \\
\hline Temporal regularity & 4.205 & -.74893 & 4.289 & -.11768 & 4.930 & .61568 & $10.986^{* *}$ \\
\hline Space & 2.641 & .16824 & 2.656 & .43644 & 1.860 & -.62285 & $8.693^{* *}$ \\
\hline Autonomy & 3.692 & -.88228 & 5.167 & .71710 & 4.421 & -.28603 & $22.015^{* *}$ \\
\hline Conflict Avoidance & 3.923 & -.39659 & 4.111 & -.37848 & 5.211 & .69967 & $11.118^{* *}$ \\
\hline $\begin{array}{l}\text { Ideology of } \\
\text { uncertainty }\end{array}$ & 2.897 & -.85375 & 4.456 & .62043 & 3.754 & -.18994 & $15.495^{* *}$ \\
\hline Total Sample & \multicolumn{2}{|c|}{$\mathrm{N}=14$} & \multicolumn{2}{|c|}{$\mathrm{N}=26$} & \multicolumn{2}{|c|}{$\mathrm{N}=22$} & \\
\hline
\end{tabular}

Following the result of cluster analysis in Table 6, we interpreted the different patterns of RDI factors across the three couples type. In doing so, we compared the type possess by each participant to their spouse's to consider whether they both form a pure couple type or a mixed couple type. Our analysis yielded that there were only 10 people classified as a separated couple, 12 people as traditional couples, two people as 
independent couples, and the remaining 38 people form a mixed couple. Since there is only one pair who classify as independent type couple, we decided not to include this data in answering the first research question since there is a limited variance related to the limited number of sample within a group for doing a comparison (Gravetter and Wallnau, 2007).

Furthermore, we conducted a one-way ANOVA analysis using SPSS 17.0 software to answer all the research questions. With this technique, we can evaluate the significance of the difference in the variable between groups of participants (Gravetter and Wallnau, 2007). In this case, a numerical score being compared is the total score of RDAS, while the group refers to the couple types as obtained from the RDI instrument.

\section{Results}

Table 7 depicts that couples who classified as traditional type had a larger RDAS total score compared to the other. This type also has the highest average score on each RDAS dimensions respectively.

Table 7

Distribution of RDAS Score for Each Dimension based on Couple Types

\begin{tabular}{|c|c|c|c|c|c|c|c|c|c|}
\hline \multirow{3}{*}{ Couple Types } & \multirow{3}{*}{$\mathrm{N}$} & \multicolumn{8}{|c|}{ RDAS Score } \\
\hline & & \multicolumn{2}{|c|}{ Total } & \multicolumn{2}{|c|}{ Consensus } & \multicolumn{2}{|c|}{ Satisfaction } & \multicolumn{2}{|c|}{ Cohesion } \\
\hline & & $\sum \mathrm{X}$ & $\mathrm{M}$ & $\sum \mathrm{X}$ & $\mathrm{M}$ & $\sum \mathrm{X}$ & $\mathrm{M}$ & $\sum X$ & M \\
\hline Separated & 10 & 540 & 54 & 252 & 25.20 & 166 & 16.60 & 122 & 12.2 \\
\hline Traditional & 12 & 723 & 60.25 & 315 & 26.25 & 214 & 17.83 & 194 & 16.17 \\
\hline Mixed & 38 & 2160 & 56.84 & 970 & 25.53 & 664 & 17.47 & 526 & 13.84 \\
\hline Total & 60 & 3542 & 57.13 & 1529 & 25.68 & 1082 & 17.45 & 868 & 14 \\
\hline
\end{tabular}

A one-way ANOVA analysis is conducted to answer the first research question. As can be seen from Table 8, it shows that there are significant differences in the total RDAS score between traditional, separated, and mixed types in the couple who married through ta'aruf $(\mathrm{F}=3.569 ; p=.035)$. Further analysis using the Scheffe test showed that the group that had significantly different RDAS scores were traditional and separated groups $(p=.037)$.

Table 8

The Difference in RDAS Score for All Sample, Male, and Female Groups of Couple Types

\begin{tabular}{lrrrrc}
\hline \multicolumn{1}{c}{ SS } & Df & M & F & Sig. \\
\hline Total sample & & & & & \\
Between groups & 217.547 & 2 & 108.774 & 3.569 & .035 \\
Within groups & 1737.303 & 57 & 30.479 & & \\
Total & 1954.850 & 59 & & & \\
Male & & & & & \\
Between groups & 202.108 & 2 & 101.054 & 3.807 & .035 \\
Within groups & 716.692 & 27 & 26.544 & & \\
Total & 918.800 & 29 & & & \\
Female & & & & & \\
Between groups & 177.677 & 2 & 88.833 & 2.943 & .070 \\
Within groups & 815.033 & 27 & 30.186 & & \\
Total & 992.700 & 29 & & & \\
\hline
\end{tabular}

For answering the second and third research questions, the couple type used is based on the results of initial cluster analysis for each male and female participant (see Table 8). 
The result of one way ANOVA showed that there is a significant difference in the total RDAS score between traditional, separated, and independent types in men who married through ta'aruf $(\mathrm{F}=3.807 ; p=.035)$. Further analysis with the Scheffe test showed that the group that is significantly different in RDAS scores were men of traditional and independent type couple $(p=.048)$. In contrast, for the female participant, the result infers that there were no significant differences in the total RDAS score between the groups of couple types $(\mathrm{F}=2.943 ; p=.070)$.

An additional analysis was explored to determine the difference among each RDAS component between the three couple types (see Table 9). We found that the result of one way ANOVA test on the component of cohesion produced a value of $\mathrm{F}=3.281(p=.045)$. Thus, the F value is significant, which means that there are differences in the mean scores of the RDAS cohesion component between the traditional, separated, and mixed couple types. Further analysis using the Scheffe test showed that the traditional and separated couple types are the groups that make a significant difference $(p=.037)$.

Table 9

The Difference in Marital Satisfaction Dimension Score for Each Couple Types

\begin{tabular}{lrrrcc}
\hline \multicolumn{1}{c}{ SS } & df & M & F & Sig. \\
\hline Consensus & & & & & \\
Between groups & 6.860 & 2 & 3.430 & .737 & .483 \\
Within groups & 265.324 & 57 & 4.655 & & \\
Total & 272.183 & 59 & & & \\
Satisfaction & & & & & \\
Between groups & 8.860 & 2 & 4.430 & 1.376 & .261 \\
Within groups & 183.540 & 57 & 3.220 & & \\
Total & 192.400 & 59 & & & \\
Cohesion & & & & & \\
Between groups & 89.614 & 2 & 44.807 & 3.281 & .045 \\
Within groups & 778.319 & 57 & 13.655 & & \\
Total & 867.933 & 59 & & & \\
\hline
\end{tabular}

\section{Discussion}

Research on marital satisfaction had so far focused on individuals from western societies, especially on people from North America (Fincham and Beach, 2006). This condition led to the lacking information on marital satisfaction from other cultures, despite there might be differences in how western and non-western society perceived marriage and its functions. In western culture, love is the primary deciding factor when people are thinking about getting married. On the contrary in non-western cultures, love might not the primary factor when people are deciding to get married. This difference will lead to different variables determining marital satisfaction in non-western cultures. Research by Arif and Fatima (2015) on modern Pakistani as one of the non-western societies found that both men and women were more satisfied in arranged marriage and marriage of choice with parental acceptance than in marriage by choice without parental acceptance. The distinctness of non-western cultures in perceiving marriage and marital satisfaction made research in this area is important.

In this study, we targeted Indonesian Muslims couples who decided to marry through the ta'aruf courtship process in examining the degree of marital satisfaction in respect to the couple types they developed during marriage. The result indicates that there is a significant difference in the level of marital satisfaction between the couples of traditional, 
separated, and mixed couple types. The result of RDAS shows that the couples developed the traditional type has the highest marital satisfaction while the couples developed separated type has the lowest marital satisfaction when compared to the other types. In addition, the same pattern also applies to the particular component of marital satisfaction which is cohesion. It was found that the traditional type has the highest cohesion while the separated type also has the lowest cohesion among the other types, in which both of these types are significantly different on the cohesion component.

The results of this study are in line with previous studies which found that traditional couple type possesses highest marital satisfaction, as first articulated by Fitzpatrick in the validation of the RDI scale itself (Fitzpatrick, 1988), and then reinforced by other studies such as research by Givertz et al.(2009), which explored Caucasian race, and also by Mustafa et al. (2012), which explored the marital satisfaction among Malay. Traditional couples are characterized by their conventional ideology related to marital relations and gender roles, which emphasizes the relationship's stability, traditional customs, and interdependence (Fitzpatrick, 1988). Mustafa et al. (2012) further elaborated that Malays have a traditional ideology following the Islamic values; thus, Malays have the highest marital satisfaction when becoming the traditional couple type. In the context of ta'aruf couple, couples using this process as a form of implementing Islamic values and using the Islamic values as their guide for regulating courtship behaviors. Correspondingly, ta'aruf couples that developed traditional couple types in their marriage have the highest marital satisfaction as the Malaysian Malays compared to other couple types. Islamic religious values that underlying the ta'aruf contain lessons compatible with the conventional ideology characterized by traditional couples.

Concerning couples developing separated couple type that has the lowest marital satisfaction among the couple types in this research, a study by Givertz et al. (2009) found that the low marital satisfaction in separated type is related to their characteristics, such as of lack of involvement and time for sharing. Also, the lack of conflict resolution skills and couples' ability to communicate about their problems, are found to mostly affect long term relationship satisfaction (Taggart, Bannon, and Hammett, 2019). This situation conforms with characteristics in separated couple type, which tends to avoid conflict by not talking about it. Another research by Velotti et al. (2015) further found that habitually concealing one's feelings may impair the maintenance of close relationships. In the context of marriage, this hesitance in expressing one's emotion and avoiding conflict is a consistent predictor of low marital satisfaction and low marital quality.

This study also found that husbands who married through ta'aruf differ in their degree of marital satisfaction among different type of couple they become, but this is not the case with the wives. Especially for husband, it was found that they are at the highest marital satisfaction as the traditional couple, while the lowest marital satisfaction is found in the independent couple type. Both the traditional and independent couple type are the groups which have a significant difference in marital satisfaction among the other groups. In contrast, women did not differ in their degree of marital satisfaction in respect to the couple type the developed after marriage. Using data found in this research, it might be possible to consider marital satisfaction as a multifaceted concept that also interacting with gender. Research by Olcay Imamoğlu, Ads, and Weisfeld (2019) found that the husbands in arranged marriages tend to feel satisfied with their spouses and the partnership since it often fulfilled their marital schemas of segregated gender-role within marriage. In respect to the three couple type explored here, thus it is not surprising that the husband in the traditional couple is found to have the highest marital satisfaction since this type values the segregated gender-role too. In contrast, it appears that husbands whose type is low in 
gender role segregation might tend to feel less satisfied in their marriage (Olcay Imamoğlu, Ads, and Weisfeld, 2019). This condition of less segregated gender role is perfectly depicted by the independent couple type where unconventional gender role becomes the main feature of this type. Moreover, Olcay Imamoğlu, Ads, and Weisfeld (2019) stated that regardless the type of marriage, wives' degree of marital satisfaction is more independent by the nature of marriage but are prone to be influenced more by their husbands' negative personality characteristic such as being argumentative, irritating or nasty. Since couple types construct in current research is portraying the nature of marriage and relationship between husband and wife as couple, but not necessarily depict personal characteristic of each spouse, thus the no difference found on the wife's marital satisfaction in respect to couple type is assumed to be related with the relatively undifferentiated nature of marriage as perceived by the wife.

Preliminary research by Fitzpatrick (1988) regarding marital satisfaction in couple types also used the Dyadic Adjustment Scale (DAS) as a measure of marital satisfaction. The traditional type was significantly higher than the other in all components of the instrument (Fitzpatrick and Indvik, 1982 in Givertz et al., 2009). However, we only found a significant difference in the cohesion component of marital satisfaction specifically among the traditional and separated couple types. The cohesion dimension measures the degree of positive interaction between spouses and their joint activity. This dimension is perfectly fit to the conception of the traditional type where the degree of sharing and use of time and space is high between the spouses. In contrast, the separated type as characterized by a low degree of sharing and separated use of time and space are all the opposite characteristics of what cohesion dimension actually measures. Thus, a significant difference in cohesion among these two couple types is aligned as a by-product of the couple type main differences. In addition to the couple types characteristics, the high degree of cohesion value in traditional couples might also be related to the characteristic of the participants, who were newlywed couples with the mean duration of the marriage at 20.75 months. Even though the newlywed in their early years of marriage are facing significant personal and relational changes (Lavner, Weiss, Miller, and Karney, 2019), but this period is also suspected of having a high marital satisfaction where marriage is perceived as highly pleasant (Lamanna and Reidman, 2012; Wilmoth, Blaney and Smith, 2015). Therefore, the cohesion that measures the degree of positive interaction, closeness, and joint activity between partners occurs intensely during this period, especially for the traditional type couple. On the other hand, another dimension of satisfaction that measures the intensity and frequency of conflicts, along with a dimension of consensus that measures the belief in agreement with a partner about important matters in marriage, seems to be less salient in the newlywed couples married life.

One major limitation of this study is the unequal number of participants in each couple types where the mixed type dominates. This condition becomes the case since the researcher cannot foresee the number of people belong to each type due to the type is related to the spouses' response and vice versa. This research is also lacking in couples developing independent couple type. Therefore, it seems necessary for future studies to increase the number of participants to capture more diverse relations. Moreover, further studies are advised to conduct a more rigorous data collection where both husband and wife can participate together but fulfill their responses independent from each other; thus minimizing the number of wasted data where the partner's responds are missing. On the other hand, this research has accommodated a more accurate data collection practice gathered from both husband and wife before processing the result. Previous research by Mustafa et al. (2012) only obtained data from one individual without involving the spouse, 
where the required partner's response to classifying spouses into couple types in RDI was filled by only one particular individual. In addition, for future studies, the measurement of marital satisfaction using RDAS can consider changing the language translation to be more suitable to the Indonesian context as a way to enhance scale validity.

\section{Conclusion}

Research exploring the marital relationship in non-western society, especially concerning those who were married through ta'aruf process is still limited. This study found that there are differences in marital satisfaction where the significantly higher marital satisfaction is perceived by the couples who developed their marriage into the traditional type compared to the separated type. In addition, gender also contributes to the relationship between marital satisfaction and couple types. In male group of respondent, as a husband who married through ta'aruf, there is a significant difference in marital satisfaction between traditional and independent couple types. Again, men in the traditional type perceive a significantly higher degree of marital satisfaction among other types. However, among female group of repondent, for a woman as a wife, there is no difference in marital satisfaction between the couple types measured. The results of this study add to the existing realm of research on marital satisfaction on the couple who decided to marry through ta'aruf.

\section{References}

Anastasi, A., and Urbina, S. (1997). Psychological Testing (7th ed.). Indiana: Prentice Hall.

Arif, N., and Fatima, I. (2015). Marital satisfaction in different types of marriage. Pakistan Journal of Social and Clinical Psychology, 13(1), 36-40. Retrieved from https://ezproxy.usim.edu.my:2229/docview/1853269994/fulltextPDF/3B18A4F7241C 49F8PQ/46? accountid=33993

Baron, R. A., Byrne, D., and Branscombe, N. R. (2009). Social Psychology (12th ed.). New York: Pearson Education, Inc.

Busby, D. M., Christensen, C., Crane, D. R., and Larson, J. H. (1995). A revision of the Dyadic Adjustment Scale for use with distressed and nondistressed couples: Construct hierarchy and multidimensional scales. Journal of Marital and Family Therapy, 21(3), 289-308. https://doi.org/https://doi.org/10.1111/j.1752-0606.1995.tb00163.x

DeGenova, M. K. (2008). Intimate Relationships, Marriage, and Families. New York: McGraw-Hill.

Fincham, F. D., and Beach, S. R. H. (2006). Relationships satisfaction. In A. Vangelisti and D. Perlman (Eds.), The Cambridge Handbook of Personal Relationships (pp. 579-594). New York: Cambridge University Press.

Fitzpatrick, M. A. (1988). Between Husband and Wife: Communication in Marriage. California: SAGE Publications, Inc.

Fitzpatrick, M. A., and Best, P. (1979). Dyadic adjustment in relational types: Consensus, cohesion, affectional expression, and satisfaction in enduring relationships. Communication Monographs,49(3), https://doi.org/https://doi.org/10.1080/0363775790937600

Ghozali, I., and Fuad. (2008). Structural Equation Modeling: Teori, Konsep, dan Aplikasi dengan Program LISREL 8.80 (3rd ed.). Semarang: Badan Penerbit Universitas 
Diponegoro. (Structural Equation Modeling: Theory, Concept, and Application with LISREL 8.80Programme (3rd ed.). Semarang: Diponegoro University Board of Publisher).

Givertz, M., Segrin, C., and Hanzal, A. (2009). The association between satisfaction and commitment differs across marital couple types. Communication Research, 36(4), 561-584. https://doi.org/10.1177/0093650209333035

Goodwin, R. (1999). Personal Relationship across Culture. New York: Routledge.

Gravetter, F. J., and Forzano, L. B. (2009). Research Methods for The Behavioural Sciences (3rd ed.). Belmont: Wadsworth, Cengage Learning.

Gravetter, F. J., and Wallnau, L. B. (2007). Statistic for The Behavioral Sciences (7th ed.). New York: Thomson and Wadsworth.

Hair, J. F., Black, W. C., Babin, B. J., and Anderson, R. (2010). Multivariate Data Analysis (7th ed.). Englewood Cliffs: Prentice Hal.

Hana, L. (2012). Taaruf Proses Perjodohan Sesuai Syari Islam. Jakarta: Quanta Elex Media. (Taaruf as Courtship Process under The Islamic Law. Jakarta: Quanta Elex Media.)

Henderson, A. K., Ellison, C. G., and Glenn, N. D. (2018). Religion and relationship quality among cohabiting and dating couples. Journal of Family Issues, 39(7), 19041932. https://doi.org/10.1177/0192513X17728982

Isma, N. M. P., and Turnip, S. S. (2019). Personality traits and marital satisfaction in predicting couples' attitudes toward infidelity. Journal of Relationships Research, 10(e13), 1-5. https://doi.org/https://doi.org/10.1017/jrr.2019.10

Kaplan, F. M., and Saccuzzo, D. P. (2005). Psychological Testing: Principles, Application and Issue (6th ed.). Belmont: Thomson Wadsworth.

Kinanthi, M. R. and Sakinah, F. (2018, July). Self-disclosure, family resilience, and marital satisfaction among Moslems who married through ta'aruf process. Paper presented in Asian Association of Indigenous and Cultural Psychology, Sabah, Malaysia. $\quad$ Retrieved from https://www.researchgate.net/profile/Melok_Kinanthi/publication/333728390_Self_D isclosure_Family_Resilience_and_Marital_Satisfaction_among_Moslems_Who_Marr ied_Through_Ta\%27aruf_Process/links/5d0108804585157d15a66b74/Self-

Disclosure-Family-Resilience-and-Marital-Satisfaction-among-Moslems-WhoMarried-Through-Taaruf-Process.pdf

Kumar, R. (2019). Research Methodology: A Step-by-Step Guide for Beginners (5th ed.). London: SAGE Publication.

Lamanna, M. A., and Reidman, A. (2012). Marriages, Families, and Relationship: Making Choice in a Diverse Society (11th ed.). Belmont: Wadsworth, Cengage Learning.

Lavner, J. A., Weiss, B., Miller, J. D., and Karney, B. R. (2019). Personality change among newlyweds: Patterns, predictors, and associations with marital satisfaction over time. Developmental Psychology, 54(6), 1172-1185. https://doi.org/10.1037/dev0000491

Miller, R. (2012). Intimate Relationships (6th ed.). New York: McGraw-Hill.

Musrifah, M. (2017). Self-disclosure pasangan ta'aruf: Perspektif komunikasi interpersonal. Alamtara: Jurnal Komunikasi Dan Penyiaran Islam, 1(2), 105-119. (Self disclosure of Ta'aruf couple: Perspective from interpersonal communication. Alamtara: Journal of Communication and The Teaching of Islam, 1(2), 105-119.)

Mustafa, H., Hasim, M. J. M., Aripin, N., and Hamid, H. A. (2012). Couple types, ethnicity, and marital satisfaction in Malaysia. Applied Research in Quality of Life, 8(3), 299-317. https://doi.org/10.1007/s11482-012-9200-z

Nunnaly, J. C., and Bernstein, I. H. (1994). Psychometric theory (3rd ed.). New York: 


\section{McGraw Hill.}

Olcay Imamoğlu, E., Ads, M., and Weisfeld, C. C. (2019). What is the impact of choosing one's spouse on marital satisfaction of wives and husbands? The case of arranged and self-choice Turkish marriages. Journal of Family Issues, 40(10), 1270-1298. https://doi.org/10.1177/0192513X19835874

Papalia, D. E., Olds, S. W., and Feldman, R. D. (2009). Human Development (11th ed.). New York: McGraw-Hill.

Pusparini, A. (2012). Agar Taaruf Cinta Berbuah Pahala. Yogyakarta: Pro-U Media. (Loving through Taaruf as A Virtuous Deed. Yogyakarta: Pro-U Media.)

Spanier, G. B. (1976). Measuring dyadic adjustment: New scales for assessing the quality of marriage and similar dyads. Journal of Marriage and the Family, 38(1), 15-28. https://doi.org/10.2307/350547

Strong, B., DeVault, C., and Cohen, T. F. (2011). The Marriage and Family Experience: Intimate Relationships in A Changing Society (11th ed.). Belmont: Wadsworth Cengage Learning.

Supratman, L. P., and Mardianti, P. (2016). Komunikasi interpersonal pasangan suami istri melalui taaruf online dating. Jurnal Penelitian Komunikasi, 19(2), 165-178. https://doi.org/10.20422/jpk.v19i2.89. (Interpersonal communication between prospective husband and wife through Taaruf online dating sites. Journal of Research in Communication, 19(2), 165-178. https://doi.org/10.20422/jpk.v19i2.89.)

Taggart, T. C., Bannon, S. M., and Hammett, J. F. (2019). Personality traits moderate the association between conflict resolution and subsequent relationship satisfaction in dating couples. Personality and Individual Differences, 139, 281-289. https://doi.org/10.1016/j.paid.2018.11.036

Velotti, P., Balzarotti, S., Tagliabue, S., English, T., Zavattini, G. C., and Gross, J. J. (2015). Emotional suppression in early marriage: Actor, partner, and similarity effects on marital quality. Journal of Social and Personal Relationships, 33(3), 277-302. https://doi.org/10.1177/0265407515574466

Williams, B. K., Sawyer, S. C., and Wahlstrom, C. M. (2006). Marriage, Families, and Intimate Relationship. Boston: Pearson Education, Inc.

Wilmoth, J. D., Blaney, A. D., and Smith, J. R. (2015). Marital Satisfaction, Negative Interaction, and Religiosity: A Comparison of Three Age Groups. Journal of Religion, Spirituality and Aging, 27(2-3), 222-240. https://doi.org/10.1080/15528030.2014.997955. 